\title{
ANALISIS FAKTOR FAKTOR YANG MEMENGARUHI TURNOVER INTENTION (STUDI KASUS PADA DIVISI NEWS GATHERING MNC MEDIA)
}

\author{
Endang Gunawan, Anggraini Sukmawati \& Aida Vitayala
}

Program Magister Bisnis, Sekolah Bisnis Institut Pertanian Bogor

E-mail: egoen800@gmail.com

\begin{abstract}
ABSTRAK
Penelitian ini bertujuan untuk menguji dan menganalisis pengaruh beban kerja terhadap turnover intention, beban kerja terhadap kepuasan kerja, kompetensi terhadap kepuasan kerja, kompetensi terhadap turnover intention, pelatihan terhadap kepuasan kerja dan kepuasan kerja terhadap turnover intention. Data diambil secara langsung menggunakan kuesioner pada 202 orang responden karyawan divisi news gathering MNC Media. Metode analisis yang digunakan dalam penelitian ini adalah Structural Equation Modeling (SEM) dengan pendekatan AMOS 22. Hasil penilitain ini menunjukan Beban kerja terbukti memiliki pengaruh signfikan terhadap menurunnya kepuasan serta meningkatnya keinginan untuk keluar dari pekerjaan. Sedangkan pelatihan memberikan dampak meningkatkan kepuasan dari karyawan terhadap pekerjaannya. Pada kompetensi diketahui memberikan pengaruh positif terhadap kepuasan namun negatif pada turnover intention. Sementara itu kepuasan kerja memberikan pengaruh positif terhadap turnover intention, semakin menurun kepuasan kerja maka keinginan untuk keluar semakin tinggi.
\end{abstract}

Kata kunci : Beban Kerja, Pelatihan, Kompetensi, Kepuasan Kerja dan Intensi Turnover

\begin{abstract}
This study to analyze the effect of workload on turnover intention, workload on job satisfaction, competence on job satisfaction, competence on turnover intention, training on job satisfaction and job satisfaction on turnover intention. Data was collected through interviews using a questionnaire. Respondents in MNC Media division news gathering employees numbered 202 people. The analytical method used in this study is Structural Equation Modeling (SEM) which is processed using AMOS 22. The results of this study indicate that workloads have a significant effect on decreasing job satisfaction. Besides that the workload increases the desire to get out of work or company. Training has the effect of increasing job satisfaction from employees towards their employment. Employee competencies are known to have a positive influence on satisfaction but negative on turnover intention. While job satisfaction has a positive influence on turnover intention, the lower the job satisfaction, the higher the desire to get out.
\end{abstract}

Keywords: Workload, Training, Competency, Job Satisfaction and Turnover Intention 


\section{Endang Gunawan}

\section{Anggraini Sukmawati}

Aida Vitayala

\section{PENDAHULUAN}

Setiap perusahaan tentunya akan menghadapi fenomena keluar masuknya karyawan dalam bekerja. Fenomena tersebut dinamakan turnover. Menurut Ridlo (2012) yang dimaksud turnover yaitu proporsi jumlah anggota organisasi yang secara sukarela (voluntary) dan tidak sukarela (non voluntary) meninggalkan organisasi dalam kurun waktu tertentu. Turnover umumnya dinyatakan dalam satu tahun dan tidak boleh lebih dari sepuluh persen pertahun. Persoalan turnover juga terjadi di perusahaan media. Saat ini bisnis media terutama televisi di Indonesia masih berkategori menjanjikan para investor yang ingin menginvestasikan modalnya. Hal ini bisa dilihat dari profit yang didapat dari belanja iklan televisi pada tahun 2017 mencapai Rp. 26,38 triliun. Angka ini setiap tahunnya cenderung meningkat. Alasan lainnya jumlah penonton televisi mencapai 99,8 persen dari jumlah penduduk Indonesia dan fasilitas televisi yang bisa mencakup seluruh lapisan masyakarat menjadikan media televisi sebagai alat efektif untuk menyampaikan informasi.

MNC Media merubah strategi bisnisnya dengan melakukan integrasi di divisi news dengan menyatukan beberapa redaksi yaitu RCTI, MNCTV, GTV dan iNewstv, ditambah MNC Chaenel yakni MNC News dan IDX pada 2015. MNC Media bertujuan memperoleh pangsa pasar 40 persen pemirsa. Selain itu, MNC Media bisa melakukan efisiensi keuangan dan Sumber Daya Manusia (SDM). Namun dalam prosesnya ada beberapa persoalan muncul seperti angka turnover tiap tahunya cendrung meningkat. Hal ini terjadi di divisi news gathering. Angka turnover di divisi news gathering pasca integrasi angkanya cendrung naik (Tabel 1).

Tabel 1. Angka turnover

\begin{tabular}{lcccc}
\hline \multicolumn{1}{c}{ Job Description } & $\begin{array}{c}\text { Jumlah } \\
\text { karyawan }\end{array}$ & $\begin{array}{c}\text { Turnover } \\
\mathbf{2 0 1 5}\end{array}$ & $\begin{array}{c}\text { Turnover } \\
\mathbf{2 0 1 6}\end{array}$ & $\begin{array}{c}\text { Turnover } \\
\mathbf{2 0 1 7}\end{array}$ \\
\hline $\begin{array}{l}\text { Kameramen } \\
\text { Reporter }\end{array}$ & 207 & 18 & 16 & 25 \\
$\begin{array}{l}\text { Kordinator daerah dan } \\
\text { Kordinator liputan }\end{array}$ & 86 & 5 & 18 & 17 \\
$\begin{array}{l}\text { Jumlah } \\
\text { Presentase (\%) }\end{array}$ & 44 & 0 & 4 & 1 \\
\hline
\end{tabular}

Tabel 1 menunjukan tren turnover cenderung meningkat. Tahun 2015 turnover mencapai 6,8 persen, 2016 meningkat menjadi 11 persen kemudian 2017 kembali mengalami peningkatan menjadi 12,7 persen. Peneliti telah melakukan wawancara pendahuluan terhadap karyawan, untuk menganalisis sementara penyebab persoalan tersebut, peneliti. Dari beberapa karyawan yang telah menginformasikan, peneliti menyimpulkan ada empat variabel yang diduga bisa mempengaruhi turnover intention di divisi news 


\section{Jurnal Manajemen Teori dan Terapan \\ Tahun 11. No. 3, Desember 2018}

gathering.Variabel tersebut yang pertama adalah beban kerja. Menurut Setyawan dan Kuswati (2006) apabila beban kerja terus menerus bertambah tanpa adanya pembagian beban kerja yang sesuai, maka kinerja karyawan akan menurun. Beberapa penelitian yang berhubungan dengan variabel beban kerja mempengaruhi turnover intention, salah satunya menurut Putra dan Prihatsanti (2016) yang menyimpulkan terdapat hubungan signifikan antara beban kerja dengan turnover. Semakin tinggi beban kerja maka semakin tinggi intensi turnover begitu juga sebaliknya semakin rendah beban kerja maka semakin rendah juga turnover.

Variabel kedua merupakan kepuasan kerja. Menurut Robbins (2008), kepuasan kerja diartikan sebagai perasaan positif terhadap pekerjaan yang dilakukan seseorang atas evaluasi karakteristi. Penelitian lainyang berhubungan kepuasan kerja dengan turnover intention yaitu yang dilakukan Fadhila dan Andayani (2014) dengan hasil penelitiannya kepuasan kerja berpengaruh negatif dan signifikan terhadap turnover intention operator.

Variabel lainnya adalah pelatihan. Menurut Widodo (2015), pelatihan merupakan serangkaian aktivitas individu dalam meningkatkan keahlian dan pengetahuan secara sistematis sehingga mampu memiliki kinerja yang profesional di bidangnya. Sedangkan penelitian yang meneliti pelatihan mempengaruhi kepuasan kerja yaitu yang dilakukan Yulianto (2017), dimana kesimpulannya untuk meningkatkan kinerja melalui kepuasan kerja dalam komunikas horizontal dengan melakukan pelatihan.

Selain itu berdasarkan hasil wawancara variabel lainnya yang diduga bisa mempengarui turnover intention melalui variabel kepuasan kerja yaitu Variabel terakhir adalah kompetensi. Kompetensi merupakan kemampuan yang mengambarkan seseorang terhadap mengitegrasikan pengetahuan, keterampilan, sikap serta nilai pribadi (Moeheriono, 2010). Hal ini sejalan dengan penelitian Ismiasih (2015) dengan hasil penelitian kompetensi berpengaruh positif dan signifikan terhadap kepuasan kerja.

Berdasarkan permasalahan tersebut, peneliti ingin mengetahui sejauh mana pengaruh beban kerja yang diterima para karyawan, kepuasan kerja dan kompetensi serta pelatihan terhadap turnover intention selama integrasi di divisi news gathering.

Tujuan penelitian ini adalah 1) Mengidentifikasi persepsi karyawan mengenai beban kerja, kompetensi, pelatihan, kepuasan dan turnover intention karyawan divisi news gathering; 2) Menganalisis pengaruh beban kerja, kompetensi, pelatihan terhadap kepuasan kerja dan turnover intention karyawan divisi news gathering. 


\section{Endang Gunawan}

\section{Anggraini Sukmawati}

Aida Vitayala

TINJAUAN PUSTAKA

\section{Kompetensi}

Menurut Azmi (2009) organisasi dapat memastikan bahwa kompetensi di tingkat output atau kinerja lebih terukur dan lebih mudah diperoleh. Salah satu cara untuk meningkatkan kompetensi adalah dengan melakukan pelatihan khusus bagi karyawan. Sedangkan menurut Itang (2015), pengembangan kompetensi dapat dilakukan dengan pembinaan dan peningkatan kapasitas dan motivasi yang dimiliki. Kompetensi merupakan kemampuan yang mengambarkan seseorang terhadap mengitegrassikan pengetahuan, keterampilan, sikap serta nilai pribadi (Moeheriono, 2010).

\section{Pelatihan}

Pelatihan merupakan serangkaian aktivitas individu dalam meningkatkan keahlian dan pengetahuan secara sistematis sehingga mampu memiliki kinerja yang profesional di bidangnya (Widodo, 2015). Pelatihan adalah proses pembelajaran yang memungkinkan pegawai melaksanakan pekerjaan yang sekarang sesuai dengan standar. Ashar et al. (2013) menyebutkan bahwa praktik SDM menunjukkan pentingnya pelatihan yang membantu dalam menciptakan sikap dan penyebab manusia yang positif untuk meningkatkan kinerja organisasi karena retensi karyawan. Hal ini menunjukkan karyawan merupakan individu yang memiliki kebutuhan untuk berkembang dengan adanya pelatihan.

Falol et al. (2014) merumuskan pengertian pelatihan dan pengembangan sebagai teknik yang digunakan untuk mentransfer ke karyawan, keterampilan, pengetahuan, dan kompetensi yang relevan untuk meningkatkan kinerja karyawan pada pekerjaan saat ini dan tugas mendatang. Hal tersebut berarti bahwa pelatihan bukan hanya sebuah metode untuk meningkatkan kemampuan berguna bagi karyawan secara pribadi, tetapi juga merupakan investasi besar bagi perusahaan untuk bisa dipetik hasilnya di masa depan.

Rivai dan Sagala (2011) mengatakan bahwa pelatihan adalah proses secara sistematis yang mengubah tingkah laku pegawai untuk mencapai tujuan organisasi. Pelatihan tersebut berkaitan dengan keahlian dan kemampuan pegawai untuk melaksanakan pekerjaan saat ini. Sementara itu menurut Noviantoro (2009), dimensi program pelatihan yang efektif yang diberikan perusahaan kepada pegawainya dapat diukur.

\section{Beban Kerja}

Beban kerja, menurut Setyawan dan Kuswati (2006), adalah beban kerja yang terus menerus bertambah tanpa adanya pembagian beban kerja yang sesuai yang 


\section{Jurnal Manajemen Teori dan Terapan \\ Tahun 11. No. 3, Desember 2018}

mengakibatkan kinerja karyawan menurun. Sedangkang menurut Sunarso (2002), beban kerja adalah sekumpulan atau sejumlah kegiatan yang harus diselesaikan oleh suatu unit organisasi atau pemegang jabatan dalam jangka waktu tertentu. Sementara itu menurut Tarwaka (2004), ada beberapa faktor yang mempengaruhi beban kerja diantaranya faktor Eksternal. Faktor eksternal beban kerja adalah beban kerja yang berasal dari luar tubuh pekerja. Aspek beban kerja eksternal sering disebut sebagai stressor.

\section{Kepuasan Kerja}

Kepuasaan kerja diartikan sebagai perasaan positif terhadap pekerjaan yang dilakukan seseorang atas evaluasi karakteristik (Robbins, 2008). Kepuasaan kerja merupakan keadaan emosional yang menyenangkan atau tidak menyenangkan terhadap pekerjaan (Handoko, 2008). Lum et al. (1998) mengatakan bahwa kepuasan gaji dapat diartikan bahwa seseorang akan terpuaskan dengan gajinya ketika persepsi terhadap gaji dan apa yang mereka peroleh sesuai dengan yang diharapkan. Beberapa penelitian mengidentifikasi aspek kepuasan yang ditemukan berhubungan dengan keinginan individu untuk meninggalkan organisasi meliputi kepuasan akan upah dan promosi.

Menurut Heneman dan Schwab dalam Andini (2006), kepuasan gaji merupakan konstruk kepuasan yang multidimensi yang terdiri atas empat subdimensi, yaitu: tingkat gaji (pay level), struktur atau pengelolaan gaji (pay structure and administration), peningkatan gaji (pay raise) dan tunjangan (benefit). Terdapat beberapa faktor penting yang dapat mengambarkan kepuasaan kerja adapun diantarannya Work it self, Salary, Promotion, Supervision, Job patner (Robbins, 2008).

\section{Turnover Intention}

Lum et al. (1998) mengatakan bahwa intensi turnover adalah keinginan seseorang untuk kelvar organisasi, yaitu melakukan evaluasi mengenai posisi seseorang yang saat ini berkenaan dengan ketidakpuasan. Hal tersebut dapat memicu keinginan seseorang untuk keluar dan mencari pekerjaan lain. Mathis dan Jackson dalam Andini (2006) menyebutkan bahwa turnover intention adalah proses dimana tenaga kerja meninggalkan organisasi dan harus ada yang menggantikannya. Terdapat faktor penting yang dijelaskan oleh Novliadi (2007), diantaranya adalah Usia, lama kerja, tingkat pendidikan dan keterikatan.

Tinjauan literatur memberikan landasan berpikir untuk menyusun kerangka pemikiran penelitian tentang analisi faktor-faktor yang memengaruhi turnover intention di divisi news gathering MNC Media. Kerangka pemikiran penelitan ini disajikan oleh Gambar 1. 


\section{Endang Gunawan}

\section{Anggraini Sukmawati}

\section{Aida Vitayala}

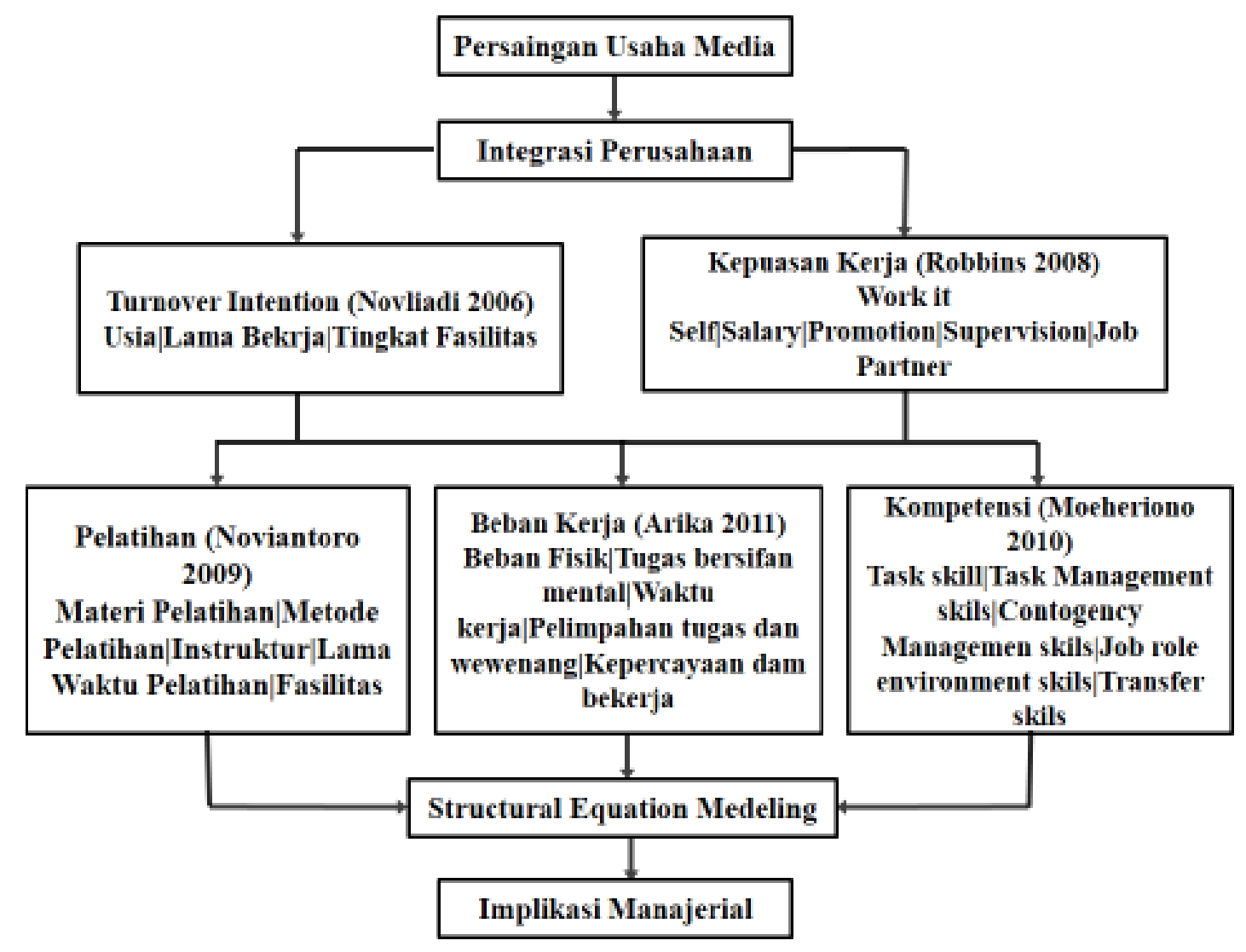

Gambar 1. Kerangka Pemikiran Penilitian

Berdasarkan latar belakang teoritis dan hasil penelitian terdahulu, maka disusun hipotesis penelitian berikut:

$\mathrm{H}_{1}=$ Beban kerja mempengaruhi turnover intention

$\mathrm{H}_{2}=$ Beban kerja mempengaruhi kepuasan kerja

$\mathrm{H}_{3}=$ Kompetensi mempengaruhi kepuasan kerja

$\mathrm{H}_{4}=$ Kompetensi mempengaruhi turnover intention

$\mathrm{H}_{5}=$ Pelatihan mempengaruhi kepuasan kerja

$\mathrm{H}_{6}=$ Kepuasan kerja mempengaruhi turnover intention

\section{METODE PENELITIAN}

Penelitian bersifat kuantitatif dengan pendekatan asosiatif. Dimana hal ini didasari dari pendekatan yang digunakan dalam memecahkan masalah yang tejadi dalam penelitian. Selain itu penelitian menggunakan data bersifat cross section, dimana hal ini berfokus pada suatu titik waktu dengan suatu kasus saja (Tabel 2). 


\begin{tabular}{|c|c|c|c|}
\hline Variabel & Definisi & Indikator & $\begin{array}{c}\text { Skala } \\
\text { Pengukuran }\end{array}$ \\
\hline $\begin{array}{c}\text { Beban Kerja } \\
\text { (Soleman, 2011) }\end{array}$ & $\begin{array}{l}\text { Beban kerja merupakan } \\
\text { frekuensi kegiatan rata-rata } \\
\text { dari masing-masing pekerjaan } \\
\text { dalam jangka waktu tertentu. }\end{array}$ & $\begin{array}{l}\text { 1. Beban fisik } \\
\text { 2. Tugas yang bersifat } \\
\text { mental } \\
\text { 3. Waktu kerja } \\
\text { 4. Pelimpahan tugas } \\
\text { dan wewenang } \\
\text { 5. Kepercayaan } \\
\text { dalam bekerja }\end{array}$ & $\begin{array}{c}\text { Ordinal } \\
\text { (1= Sangat } \\
\text { Tidak Setuju } \\
\text { s/d 5=Sangat } \\
\text { Setuju) }\end{array}$ \\
\hline $\begin{array}{l}\text { Kepuasan Kerja } \\
\text { (Robbins, 2008) }\end{array}$ & $\begin{array}{l}\text { Kepuasaan kerja diartikan } \\
\text { sebagai perasaan positif } \\
\text { terhadap pekerjaan yang } \\
\text { dilakukan seseorang atas } \\
\text { evaluasi karakteristik. }\end{array}$ & $\begin{array}{l}\text { 1. Work it self } \\
\text { 2. Salary } \\
\text { 3. Promotion } \\
\text { 4. Supervision } \\
\text { 5. Job patner }\end{array}$ & $\begin{array}{c}\text { Ordinal } \\
\text { (1= Sangat } \\
\text { Tidak Setuju } \\
\text { s/d 5=Sangat } \\
\text { Setuju) }\end{array}$ \\
\hline $\begin{array}{c}\text { Pelatihan } \\
\text { (Noviantoro,2009) }\end{array}$ & $\begin{array}{l}\text { Pelatihan adalah proses } \\
\text { secara sistematis mengubah } \\
\text { tingkah laku pegawai untuk } \\
\text { mencapai tujuan organisasi. }\end{array}$ & $\begin{array}{l}\text { 1. Materi pelatihan } \\
\text { 2. Metode pelatihan } \\
\text { 3. Instruktur } \\
\text { 4. Lama waktu } \\
\text { pelatihan } \\
\text { 5. Fasilitas }\end{array}$ & $\begin{array}{c}\text { Ordinal } \\
\text { (1= Sangat } \\
\text { Tidak Setuju } \\
\text { s/d 5=Sangat } \\
\text { Setuju) }\end{array}$ \\
\hline $\begin{array}{l}\text { Turnover Intention } \\
\text { (Novliadi, 2007) }\end{array}$ & $\begin{array}{l}\text { Keinginan seseorang untuk } \\
\text { keluar dari organisasi. }\end{array}$ & $\begin{array}{l}\text { 1. Usia } \\
\text { 2. Lama bekerja } \\
\text { 3. Tingkat pendidikan } \\
\text { 4. Keterikatan }\end{array}$ & $\begin{array}{c}\text { Ordinal } \\
\text { (1= Sangat } \\
\text { Tidak Setuju } \\
\text { s/d 5=Sangat } \\
\text { Setuju) }\end{array}$ \\
\hline $\begin{array}{l}\text { Kompetensi } \\
\text { (Moeheriono, } \\
\text { 2010) }\end{array}$ & $\begin{array}{l}\text { Kompetensi merupakan } \\
\text { kemampuan yang } \\
\text { mengambarkan seseorang } \\
\text { terhadap mengitegrassikan } \\
\text { pengetahuan,keterampilan, } \\
\text { sikap serta nilai pribadi. }\end{array}$ & $\begin{array}{l}\text { 1.Task skill } \\
\text { 2.Task management } \\
\text { skills } \\
\text { 3. Contogency } \\
\text { management skill } \\
\text { 4.Job role } \\
\text { environment skills } \\
\text { 5.Transfer skill }\end{array}$ & $\begin{array}{c}\text { Ordinal } \\
\text { (1= Sangat } \\
\text { Tidak Setuju } \\
\text { s/d 5=Sangat } \\
\text { Setuju) }\end{array}$ \\
\hline
\end{tabular}

Data yang digunakan dalam penelitian ini terdapat dua jenis yaitu: 1) Data primer didapatkan dari hasil wawancara melalui kuisioner dari responden para karyawan divisi News Gathering MNC Media; Skala pengukuran menggunakan Skala Likert 1-5; 2) Data sekunder didapat melalui sumber seperti studi literatur, perusahaan MNC Media, Kominfo (2017), serta sumber lainnya. Metode pengambilan sample dalam penelitian ini adalah random sampling dengan mengambil sample berjumlah 202 orang dari 337. Sugiyono (2013) menjelaskan bahwa ukuran kelayakan sampel dalam penelitian sosial adalah berjumlah diantara 30 orang hingga 500 orang. 


\section{Endang Gunawan}

Anggraini Sukmawati

Aida Vitayala

Tabel 3. Populasi dan sample (contoh)

\begin{tabular}{lcc}
\hline Job Description & Populasi (orang) & Sample (orang) \\
\hline Kameramen & 207 & 112 \\
Reporter & 86 & 60 \\
Kordinator Daerah & 22 & 15 \\
Kordinator Liputan & 22 & 15 \\
\hline Jumlah & 337 & 202 \\
\hline
\end{tabular}

\section{Teknik Pengolahan dan Analisis Data}

Analisis deskriptif yang digunakan dalam penelitian ini ditujukan untuk mengetahui dan mendeskripsikan hubungan yang terjadi dalam penelitian. Analisis pengujian hipotesa penelitian menggunakan analisis SEM (Structural Equatuion Modelling) AMOS 22 dengan hubungan variabel dan kriterianya dapat dilihat pada Gambar 4.

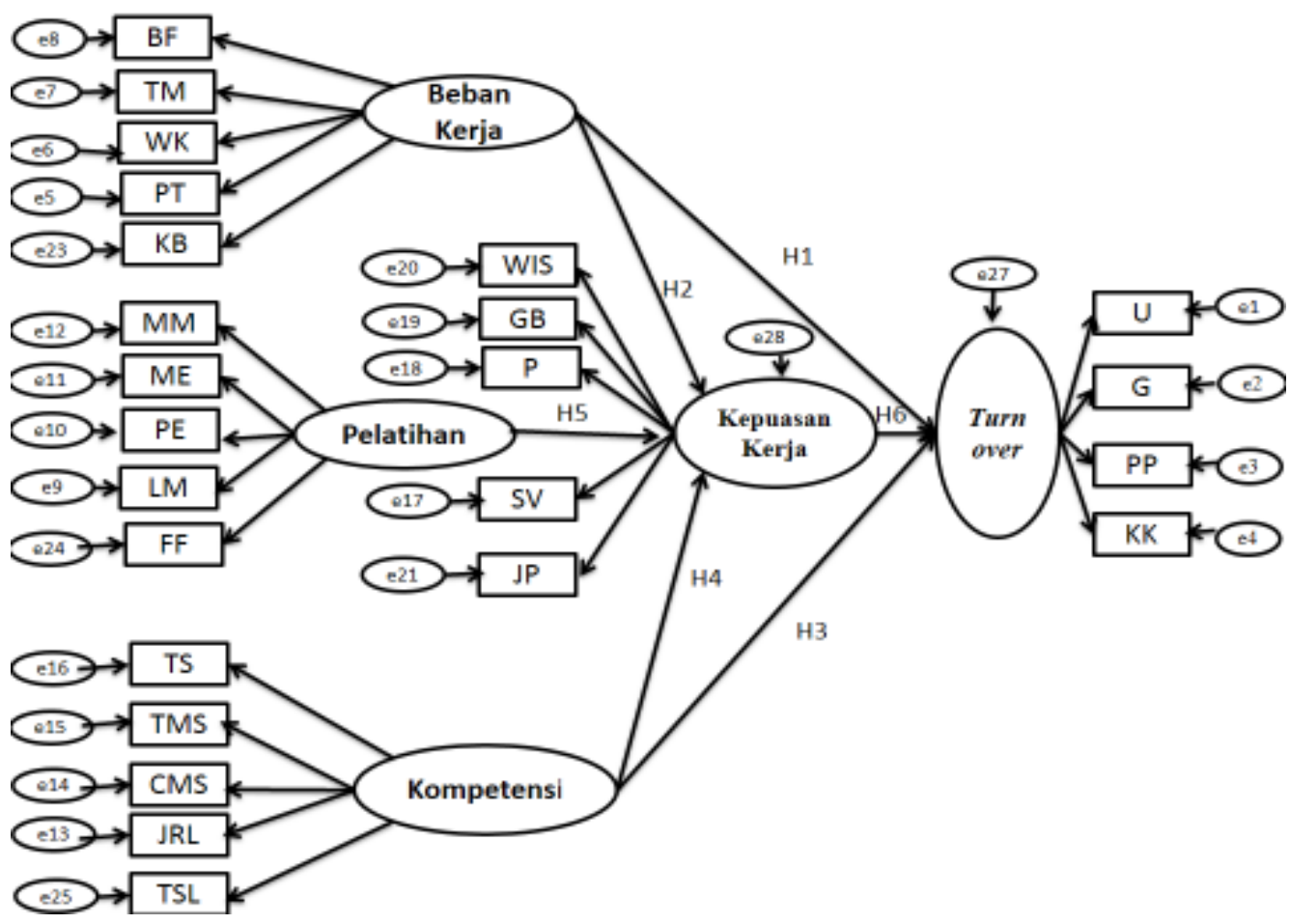

Gambar 2. Model Structural Equation Modeling

Keterangan: BF: Beban fisik, TM: Tugas yang bersifat mental, WK: Waktu kerja, PT: Pelimpahan tugas dan wewenang, KB: Kepercayaan dalam bekerja, MM: Materi pelatihan, ME: Metote pelatihan, PE: Instruktur, LM: Lama waktu pelatihan,FF. Fasilitas, TS: Task skill, TMS: Task management skills, CMS: Contogency management skill, JRL: Job role environment skills, TSL: Transfer skill, WIS: Work it self, GB: Salary, P: Promotion, SV: Supervision, JP: Job patner, U: Usia, G: Lama bekerja, PP: Tingkat pendidikan, KK: Keterikatan dan el-e25 Eror. 


\section{HASIL DAN PEMBAHASAN}

Uji Kecocokan Model

Uji kecocokan model dilakukan untuk mengetahui model yang diuji, apakah sesuai dengan beberapa indikator yang telah ditetapkan atau tidak. Selain itu hal ini juga digunakan untuk memastikan model untuk dapat diidentifikasi. Pada analisis Structural Equation Modeling, diketahui terdapat beberapa gambaran dapat dilihat pada tabel.

Tabel 4. Uji Kecocokan Model

\begin{tabular}{llll}
\hline Kriteria & Output & Batasan & Keterangan \\
\hline Chi Square & 847.237 & $>0.05$ & Fit \\
AGFI & 0.673 & $>0.5$ & Fit \\
PNFI & 0.633 & Positif & Fit \\
\hline Berdata
\end{tabular}

Berdasarkan Tabel 1 diketahui terdapat beberapa informasi penting terkait dengan kriteria uji kecocokan model. Pada kriteria chisquare diketahui memiliki output sebesar 847.237 dimana angka ini termasuk dalam kategori angka yang besar. Santoso (2015) menyatakan bahwa output chi-square yang besar disebabkan karena jumlah sampel yang besar serta jumlah indikator yang banyak. Disisi lain, diketahui bahwa kriteria chi-square terbukti memberikan kriteria fit akibat telah melebih batasan yang telah disesuaikan sebelumnnya.

AGFI merupakan kriteria kecocokan yang serupa dengan CFI. Diketahui bahwa output GFI dinyatakan cocok karena telah melebihi output yang ditentukan. Kriteria PNFI merupakan kriteria yang digunakan untuk menilai secara keseluruhan dan diketahui bahwa output dengan batasan dapat dinyatakan sesuai dengan kriteria kecocokan model.

Pada uji kecocokan model diketahui bahwa terdapat 3 kriteria yang dinyatakan cocok dengan model. Santoso (2015) menyatakan bahwa kecocokan model dalam analisis Structural Equation Modeling adalah minimal 1 atau lebih untuk dinyatakan cocok.

\section{Uji Hipotesis}

Pengujian ini dilakukan untuk mengetahui hubungan antara variabel dengan variabel lain. Didalam penelitian ini terdapat enam hipotesis yang ditujukan untuk mengetahui hubungan terhadap turnover intention. Selain itu model yang diolah dalam penelitian ini adalah model yang telah dikurangi beberapa dimensi yang memiliki nilai dibawah 0.5. Adapun gambar dari model keseluruhan penelitian terdapat pada Gambar 5.

Dari Gambar 3 diketahui bahwa model penelitian yang telah dilakukan pembuangan dimensi dapat dilanjutkan atau diteruskan kembali. Adapun output untuk membuktikan bahwa tidak terdapat nilai loading factor dari dimensi terdapat pada Tabel 5 seperti berikut. 


\section{Endang Gunawan}

\section{Anggraini Sukmawati}

\section{Aida Vitayala}

Berdasarkan Tabel 5 diketahui bahwa seluruh dimensi memiliki nilai diatas 0.5 , sehingga dapat dikatakan seluruh variabel layak untuk dipertahankan dalam model. Disisi lain, seluruh dimensi juga menunjukan nilai $P$ (probabilistic) dibawah 0.05 , sehingga seluruh dimensi dinyatakan signifikan dengan variabelnya. Perhitungan dilakukan pada loading factor atas hubungan variabel dengan variabel lainnya. Hal ini digunakan untuk dasar dalam merumuskan rekomendasi terbaik terkait penelitian, yang disajikan pada Tabel 3 terkait dengan loading factor dari tiap variabel.

Tabel 5. Loading Factor Hipotesis Penelitian

\begin{tabular}{lllll}
\hline Hubungan & & & Estimate & P \\
\hline U & $<---$ & turnover_intention & 0.782 & $* * *$ \\
G & $<--$ & turnover_intention & 0.984 & $* * *$ \\
PP & $<---$ & turnover_intention & 0.943 & $* * *$ \\
PT & $<---$ & BebanKerja & 0.71 & $* * *$ \\
WK & $<--$ & BebanKerja & 0.766 & $* * *$ \\
TM & $<--$ & BebanKerja & 0.666 & $* * *$ \\
MM & $<--$ & Pelatihan & 0.895 & $* * *$ \\
PE & $<--$ & Pelatihan & 0.929 & $* * *$ \\
ME & $<--$ & Pelatihan & 0.906 & $* * *$ \\
JRL & $<---$ & Kompetensi & 0.776 & $* * *$ \\
CMS & $<---$ & Kompetensi & 0.81 & $* * *$ \\
TMS & $<---$ & Kompetensi & 0.866 & $* * *$ \\
TS & $<--$ & Kompetensi & 0.847 & $* * *$ \\
SV & $<--$ & Kepuasan & 0.789 & $* * *$ \\
P & $<--$ & Kepuasan & 0.772 & $* * *$ \\
GB & $<--$ & Kepuasan & 0.693 & $* * *$ \\
WIS & $<--$ & Kepuasan & 0.769 & $* * *$ \\
JP & $<--$ & Kepuasan & 0.623 & $* * *$ \\
FF & $<--$ & Pelatihan & 0.781 & $* * *$ \\
TSL & $<--$ & Kompetensi & 0.711 & $* * *$ \\
\hline
\end{tabular}

Tabel 6. Loading Factor dari Variabel Penelitian

\begin{tabular}{lccccl}
\hline \multicolumn{2}{c}{ Hubungan antar Variabel } & Estimate & P & \multicolumn{1}{c}{ Keterangan } \\
\hline Kepuasan & $<--$ & BebanKerja & -0.279 & 0.001 & Negatif \& Signifikan \\
Kepuasan & $<--$ & Kompetensi & 0.336 & ${ }^{* * *}$ & Positif \& Signifikan \\
Kepuasan & $<--$ & Pelatihan & 0.505 & ${ }^{* * *}$ & Positif \& Signifikan \\
turnover_intention & $<--$ & Kepuasan & 0.426 & ${ }^{* * *}$ & Positif \& Signifikan \\
turnover_intention & $<--$ & BebanKerja & -0.261 & 0.005 & Negatif \& Signifikan \\
turnover_intention & $<--$ & kompetensi & -0.05 & 0.6 & Negatif \& Tidak Signifikan \\
\hline
\end{tabular}




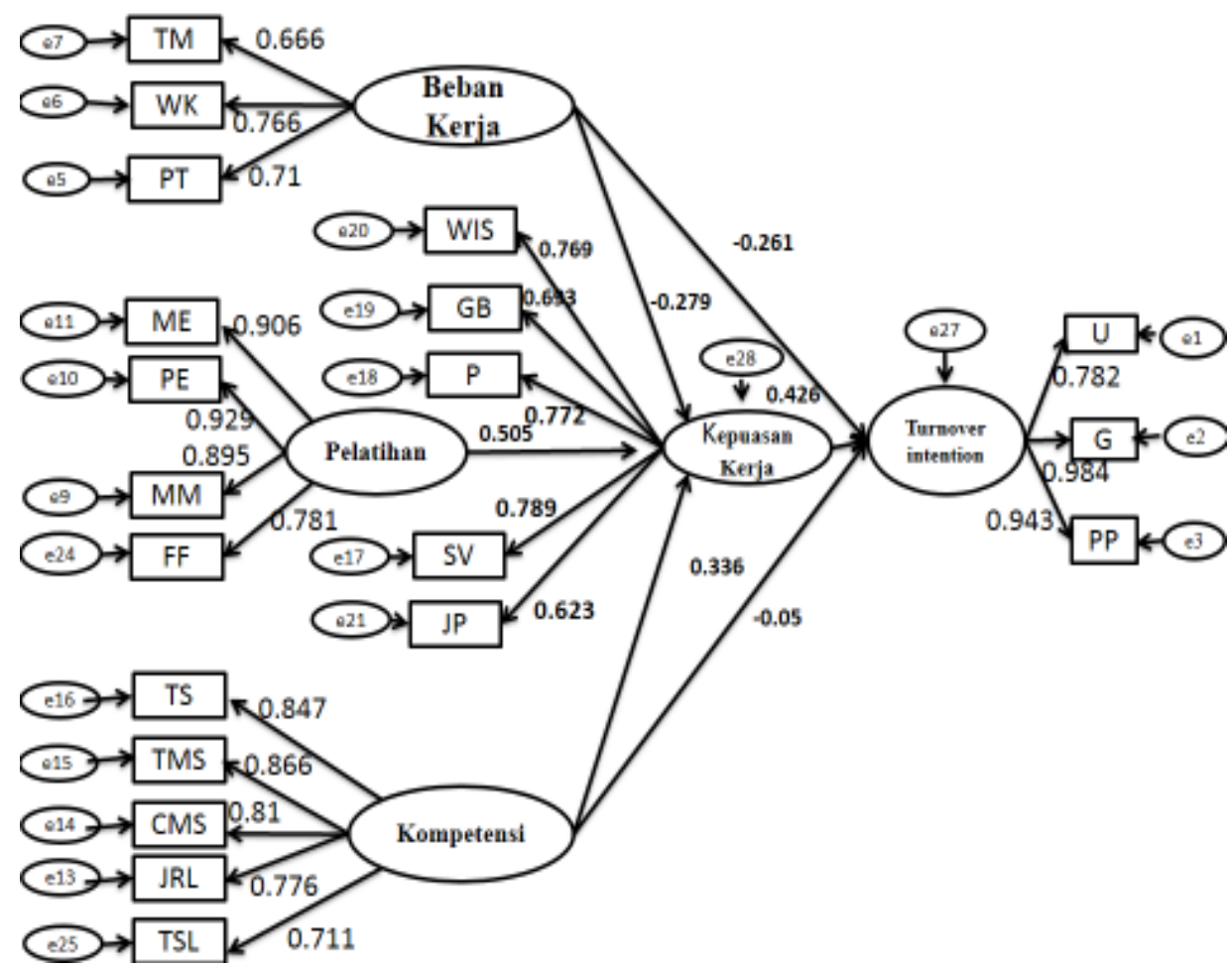

Gambar 3. Model SEM Akhir

Berdasarkan Tabel 6 diketahui beberapa gambaran besar yang menjelaskan mengenai hipotesis dari penelitian. Gambaran penjelasan dari tiap hipotesis tersebut adalah seperti berikut:

\section{H1: Pengaruh beban kerja terhadap turnover intention.}

Hubungan beban kerja terhadap turnover intention secara langsung juga terbukti memiliki pengaruh negatif (-0.261) dan signifikan (0.05). Hal ini disebabkan oleh hal yang sama yaitu bertambahnya waktu kerja untuk menyelesaikan pekerjaan, pelimpahan tugas yang cukup banyak serta tugas dengan tantangan mental yang tinggi. Disisi lain peranan dari beban kerja terbukti kuat baik secara langsung maupun tidak langsung. Hal ini sesuai dengan penelitian oleh Askiyanto et al. (2018) menjelaskan bahwa hubugan beban pekerjaan karyawan memiliki pengaruh negatif serta signifikan terhadap keinginan untuk keluar dari pekerjaan, hal ini disebabkan terlalu besar beban dan stress dalam menghadapi tiap pekerjaannya. Erat et al. (2017) telah menjelaskan bahwa memiliki pengaruh signifikan terhadap keinginan untuk keluar dari pekerjaan.

\section{H2: Beban kerja terhadap kepuasan kerja.}

Diketahui hubungan antara beban kerja terhadap kepuasan kerja karyawan memiliki nilai negatif $(-0.279)$ dan signifikan $(0.01<0.05)$. Hal ini juga mengambarkan bahwa semakin besar beban kerja yang diterima oleh para karyawan maka akan memberikan dampak terhadap 


\section{Endang Gunawan}

\section{Anggraini Sukmawati}

\section{Aida Vitayala}

menurunya kepuasan dari karyawan. Disisi lain, diketahui bahwa hal ini disebabkan bertambahnya waktu kerja untuk menyelesaikan pekerjaan, pelimpahan tugas yang cukup banyak, serta tugas dengan tantangan mental yang tinggi. Hal ini sejalan dengan penelitian dari Sahin dan Sahingoz (2013) yang menjelaskan bahwa terdapat hubungan besar antara beban kerja dengan kepuasan kerja. Dijelaskan bahwa perusahaan harus mampu mengorganisasikan karyawannya agar beban kerja dapat sesuai dengan pekerjaaya sehingga pekerjaan dapat berjalan dengan baik serta kepuasan dari karyawan dapat terjaga. Selain itu dalam penelitian yang dilakukan oleh Goetz et al. (2013), diketahui bahwa beban kerja dapat memiliki pengaruh terhadap kepuasan kerja akibat manajer selalu memberikan waktu lembur kepada karyawannya. Oleh karena itu, diperlukan sebuah langkah yang dapat mengatur jadwal lembur yang lebih baik.

\section{H3: Pengaruh kompetensi terhadap kepuasan kerja}

Hubungan variabel kompetensi terhadap kepuasan kerja terbukti memiliki pengaruh positif (0.336) dan signifikan $(* * *<0.05)$. Hal ini disebabkan dari perusahaan telah memiliki standard dalam menerima karyawan yang memiliki kemampuan dalam task management, contingency management, job role dan transfer skill yang layak. Hal ini sejalan dengan penelitian dari Francis (2015) yang menyatakan bahwa kompetensi memiliki pengaruh terhadap kepuasan kerja, namun hal ini perlu dibedakan lebih lanjut dari deskripsi jenis kelamin serta pendidikannya.

\section{H4: Pengaruh kompetensi terhadap turnover intention.}

Diketahui hubungan antara variabel komptensi dengan turn over intention terbukti memiliki pengaruh negatif $(-0.05)$ namun tidak signifikan $(0.6<0.05)$. Hal ini disebabkan keinginan turnover lebih besar dampaknya disebabkan oleh faktor lain diluar kompetensi dari pegawai tersebut. Dalam penelitian Saraih dan Aris (2016) menjelaskan bahwa kompetensi karyawan memiliki pengaruh terhadap turnover intention dimana hal ini disebabkan oleh pengetahuan terkait dengan kemampuan karyawan dalam bekerja.

\section{H5: Pengaruh pelatihan terhadap kepuasan kerja.}

Hubungan antara pelatihan yang diberikan perusahaan terhadap kepuasan kerja memiliki pengaruh positif $(0.505)$ dan signifikann $(* * *<0.05)$. Hal ini disebabkan karena perusahaan mampu memberikan komposisi yang mampu mengembangkan karyawan dengan menggunakan materi yang berkualitas,berkualitas. Perusahaan juga mampu memberikan metode yang baik serta pengajar yang berpengalaman dalam bidangnya. Hal ini sesuai dengan penelitian Karimi dan Nejad (2018) yang menjelaskan bahwa pelatihan tersebut 
memiliki pengaruh terhadap kepuasan dari para pekerja. Hal ini disebabkan pelatihan memberikan informasi dan pengetahuan dalam bekerja yang baik. Selain itu, para karyawan diajak untuk lebih tahu, sehingga nyaman dengan kondisi pekerjaannya. Sejalan dengan penelitian yang dilakukan oleh Terera dan Ngirande (2014), pelatihan memberikan dampak besar bagi kepuasan kerja karyawan yang disebabkan dari pengenalan perusahaan dan tatacara bekerja yang baik sehingga karyawan telah lebih dahulu.

\section{H6: Pengaruh Kepuasan kerja terhadap turnover intention.}

Hubungan antara variabel kepuasan dengan turnover intention terbukti memiliki pengaruh positif (0.426) dan signifikan (***<0.05). Hal ini disebabkan tidak tercapainya beberapa hal penting sepeti kesempatan untuk berkembang, promosi, peranan pimpinan dan partner dalam bekerja. Hal ini sesuai dengan penelitian dari Saed et al. (2014) yang menjelaskan bahwa hubungan antara pengaruh kepuasan terhadap keinginan untuk keluar pekerjaan terbukti memberikan hasil yang signifikan. Hal ini disebabkan atas kepuasan kerja memberikan rasa nyaman pada karyawan bekerja, atas dasar tersebut keinginan untuk keluar atau bertahan di tempat kerja yang sama juga dapat dipertahankan.

\section{Implikasi Manajerial}

Berdasarkan seluruh output tersebut diketahui terdapat beberapa hal penting yang dapat dijadikan rekomendasi bagi manajemen disetiap variabelnya, diantaranya:

\section{Turnover intention}

Diperlukan sebuah prosedur yang mampu menjaga keinginan karyawan yang ingin keluar agar tidak menjadi sebuah aksi nyata, sehingga dapat memberikan pengaruh besar terhadap jalannya perusahaan. Salah satunya yang perlu diperhatikan oleh perusahaan adalah rendahnya gaji yang diterima dibanding dengan besarnya tawaran gaji dari perusahaan kompetitor atau lainnya.

\section{Beban Kerja}

Beban kerja memberikan peranan kuat terhadap variabel kepuasan kerja dan turnover intention. Perlu adanya sistem pembagian pekerjaan dalam melakukan peliputan agar kualitas pekerjaan lebih terjaga dan pekerjaan dilakukan sesuai dengan job desknya. Ada beberapa indikator yang dianggap karyawan menjadi beban kerja diantaranya waktu kerja yang melebihi batas ketentuan dimana karyawan sering bekerja lebih dari waktu jam kerja yang ditentukan perusahaan. Pelimpahan tugas seperti permintaan live dan liputan dalam waktu bersamaan dari tv group. Hal ini bisa diatasi dengan kebijakan menambah tim liputan di lokasi yang sama agar tim liputan bisa berbagi tugas. Indikator lainnya berupa tekanan 


\section{Endang Gunawan}

\section{Anggraini Sukmawati}

\section{Aida Vitayala}

mental seperti tekanan dari atasan saat bekerja, baik berupa teguran dan tugas-tugas dadakan. Penyampaian yang baik dari atasan ke bawahan sangat diperlukan agar bisa diterima dengan baik.

\section{Pelatihan}

Perusahaan perlu melakukan pelatihan dengan melakukan simulasi pekerjaan dengan beban yang beragam. Dengan metode pelatihan tersebut diharapkan dapat menyiapkan mental dari karyawan terhadap beratnya pekerjaan jurnalis. Pelatihan perlu dilakukan terutama bagi karyawan yang tidak memiliki skill jurnalis.

\section{Kompetensi}

Meskipun kompetensi bukan faktor utama, turnover intention karena hasil penelitian $(0,6<0,05)$ tidak siginikan namun perusahaan harus memperhatikan variabel tersebut. Pada proses rekrutment perusahaan perlu mengkaji dengan baik pertimbangan kompetensi dari calon karyawan. Hal ini dianggap dapat memberikan dampak terhadap kesiapan karyawan dalam bekerja. Karyawan yang telah mengetahui sistem bekerja, budaya kerja serta medan dari pekerjaan jurnalis akan kuat dalam menghadapi segala beban pekerajaan yang membuat dirinya tidak ingin keluar dari pekerjaannya.

\section{Kepuasan Kerja}

Kepuasan kerja merupakan perasaan positif terhadap pekerjaan, bagi manajeman jika hal itu bisa terlaksana maka perlu memperhatikan beberapa indikator sepeti kesempatan untuk berkarir dan promosi. Pada indikator ini perusahaan tidak terlalu membuka ruang bagi karyawannya untuk dipromosikan atau mengembangkan karirnya, untuk itu perlunya jenjang karir. Besaran bonus yang diinginkan karyawan tidak melihat dari penilaian kerja dan perusahaan juga perlu memperhatikan besarnya tunjungan karyawan.

\section{SIMPULAN}

Persepsi karyawan divisi news gathering terkait dengan beban kerja menunjukkan bahwa perusahaan memberikan pekerjaan yang berat terhadap karyawan. Pada variabel pelatihan, diketahui bahwa perusahaan mampu memberikan materi, metode serta instruktur yang bisa dipahami karyawan dan sesuai kebutuhan pekerjaan. Pada variabel kompetensi diketahui bahwa karyawan memiliki kemampuan sesuai keahliannya dalam bekerja. Disisi lain persepsi kepuasan karyawan sangat beragam namun masih masuk dalam kategori puas. Disisi lain banyak karyawan yang ingin menyatakan untuk keluar dari pekerjaannya. 
Beban kerja terbukti memiliki pengaruh signfikan terhadap menurunnya kepuasan serta meningkatnya keinginan untuk keluar dari pekerjaan. Sedangkan pelatihan memberikan dampak meningkatkan kepuasan dari karyawan terhadap pekerajaannya. Kompetensi diketahui memberikan pengaruh positif terhadap kepuasan namun negatif pada turnover intention. Sementara itu kepuasan kerja memberikan pengaruh positif terhadap turnover intention. Semakin menurun kepuasan kerja maka keinginan untuk keluar semakin tinggi.

Perusahaan perlu mengkaji dengan baik beban kerja sehingga keinginan untuk keluar perusahaan dapat menurun. Hal ini juga untuk menjaga perusahaan agar tetap memiliki karyawan yang berkualitas. Penelitian ini diketahui masih memiliki banyak kelemahan, oleh karena itu penulis menyarankan untuk mengkaji terkait dengan perbedaan demografi responden terhadap beban kerja dan turnover intention.

\section{DAFTAR PUSTAKA}

Ashar et al. 2013. The Impact of Perceptions of Training on Employee Commitment and turnover Intention: Evidence from pakistan.International Journal of Human Resource Studies, 3(1).

Askiyanto, Soejipto M., Eko B., \& Suharto. 2018. The Effect of Workload, Work Stress and Organizational Climate on Turnover Intention with Work Satisfaction as an Intervening Variable (Study at PT BRI Life and Health Insurance of Malang). European Journal of Business and Management. 10(12): 61-70.

Azmi, Ilhaamie Abdul Ghani. 2010. Competency-based human resource practices in Malaysian public sector organizations. African journal of business management 4(2):235-241.

Erat, Serhat., Kitapci, Hakan., \& Comez, Pinar. 2017. The Effect of Organizational Loads on Work Stress, Emotional Commitment, and Turnover Intention. International Journal of Organizational Leadership. (5) 1: 221-231.

Fadhila \& Andayani. 2014. Pengaruh Kepuasan kerja terhadap turnover intention operator tetap PT. Hino Motors Manufacturing Indoneisa. (Tesis) FISIP Universitas Indonesia.

Francis, David J. 2015. The Effects of Competency on Job Satisfaction for Professional Counselors When Providing Court Testimony. [Disertation]. Walden University.

Goetz, Katja., Musselmann, Berthold., Szecsenyi, Joachim., \& Joos, Stefanie. 2013. The Influence of Workload and Health Behavior on Job Satisfaction of General Practitioners. Family Medicine. 45(2):96-107.

Handoko, T., \& Hani. (2008). Manajemen Personalia dan Sumbe Daya Manusia (edisi 2). Yogyakarta: BPFE. 


\section{Endang Gunawan}

\section{Anggraini Sukmawati}

\section{Aida Vitayala}

HO, Falola., AO., Osibanjo, \& IS Ojo. 2014. Effectiveness of Training and Development on Employees' Performance and Organization Competitiveness in the Nigerian Banking Industry. Bulletin of the Transilvania University of Brasov. Series V: Economic.

I, Itang. 2015. Peta Kekutan Ekonomi Syariah Dalam Menghadapi Masyarakat Ekonomi Asean (Mea). ALQALAM 32 (2),331-360.

Ismiasih, W. 2015. Pengaruh kompetensi dan kompensasi terhadap kepuasan kerja perawat rumah sakit umum fatmawati. (tesis). Universitas Terbuka.

Karimi, Sima., \& Nejad, Amir HR. 2018. The Effect of Organizational Training on Job Satisfaction and Individual Performance of Ahwaz Oil Company Employees. Revista Publicando. 5(5):385-345.

Kementrian komunikasi dan infromatika (KOMINFO). 2017. Daftar izin penyiaran televisi (internet). Diakses pada: 2018 Maret 28). Tersedia pada: https://epenyiaran.kominfo.go.id/uploads/informasi/4be6453eb9b45d3e3370ede9c586ce84. pdf.

Lum, Lille., John, Kervin., Kathleen, Clark., Frank, Reid., \& Wendy, Sola. 1998. Explaining Nursing Turnover Intent: Job Satisfaction, Pay Satisfaction, or Organizational Commitment. Journal of Organizational Behavior. Vol. (19) 305-320.

MNC Group. 2016. Laporan Tahunan. Tersedia pada: http://mnc.co.id/ir/annual_reports/id\#content.

Moeheriono. 2010. Pengukuran Kinerja Berbasis Kompetensi. Surabaya: Ghalia Indonesia.

Noviantoro, Djatiko. 2009. Analisis Pengaruh Pelatihan dan Pengembangan, serta Kopensasi Terhadap Kinerja Pegawai Pada PT. Perkebunan London Sumatra Indonesia Tbk. (Thesis) Univesitas Sumatra Utara: Sumatera Utara.

Novliadi, P. 2007. Intensi Turnover Karyawan Ditinjau dari Budaya Perusahaan dan Kepuasan Kerja. Makalah: Fakultas Kedokteran, Jurusan Psikologi USU.

Putra, Mochammad Taufan Permana., Prihatsanti, Unika. 2016. Hubungan Antara Beban Kerja Dengan Intensi Turnover Pada Karyawan Di Pt. "X". Jurnal Empati, April 2016, Volume 5(2), 303-307.

Ridlo, IA. 2012. "Turnover Karyawan Kajian Literatur". Serial Paper Manajeman, Surabaya: PH Movement Publication.

Rivai, Veithzal., dan Sagala, Ella Jauvani. 2011. Manajemen Sumber Daya Manusia untuk Perusahaan dari Teori ke Praktik. Jakarta: PT Raja Grafindo.

Robbins, P Stephen. 2010. Manajemen. Erlangga: Jakarta.

Saed, Iqra., Waseem, Momina., Sikander, Sidra. 2014. The Relationship Of Turnover Intention With Job Satisfaction, Job Performance, Leader Member Exchange, Emotional 


\section{Jurnal Manajemen Teori dan Terapan \\ Tahun 11. No. 3, Desember 2018}

Intelligence And Organizational Commitment. International journal of Learning \& Development . 4(2): 242-252.

Sahin, Hande., \& Sahingoz, Akar S. 2013. The Relationship between Personnel Workload and Work Satisfaction within Accommodation and Nutrition Establishments. American International Journal of Social Science. 2(3):10-20.

Santoso, S. 2011 . Structural Equation Modeling (SEM) Konsep dan Aplikasi dengan Amos 22. Jakarta (ID): Gramedia.

Saraih, Ummi N., \& Aris, Ain Z., 2016. Factors Affecting Turnover Intention among Academician in the Malaysian Higher Educational Institution. SIBR 2016 Conference on Interdisciplinary. 2(3):1-17.

Setyawan, Kuswati. 2006. Teknologi informasi dan reposisi fungsi manajemen Sumber daya manusia. Jurnal Manajemen dan Bisnis Benefit. 10(1).

Soleman, A. 2011. Analisis beban kerja ditinjau dari faktor usia dengan pendekatan recommended weight limit. ARIKA. 5 2): 83-92.

Sugiyono. 2014. Metode Penelitian Kuantitatif, Kualitatif, dan Kombinasi (Mixed Methods). Bandung : Alfabeta.

Tarwaka. 2004. Ergonomi Industri. Surakarta: UNIBA Press.

Terera, Sharon, R., \& Ngirande, Hlanganipai. 2014. The Impact of Training on Employee Job Satisfaction and Retention among Administrative Staff Members: A Case of a Selected Tertiary Institution. Kamin Raj. 39(1):43-53.

Widodo, R. 2010. Analisis Pengaruh Keamanan Kerja dan Komitmen Organisasional terhadap Turnover Intention serta dampaknya pada Kinerja Karyawan Outsourcing. Tesis Manajemen Program Studi Magister Manajemen Universitas Diponegoro.

Yulianto, W. 2017. Pengaruh motivasi, kepemimpinan, kompetensi dan pelatihan terhadap kinerja pegawai dengan kepuasan kerja sebagai variabel mediasi. (tesis). Insititut Pertanian Bogor. 